\title{
The Spatial Agglomeration of Korean Logistics and Its Influence on the Growth of the Logistics Industry
}

\author{
Taek-Won Kim, Tae-Hwan Kim
}

\begin{abstract}
This study is to identify the spatial concentrations of logistics businesses per region, to find out how this spatial variable affects the growth of the logistics industry and the regional economy, and based on the findings, to suggest political implications for the nation and local governments regarding the logistics industry. The implications of this study are as follows. First, despite the fact that the National Logistics Master Plan (2016-2025) was established at a national level to build and operate the logistics bases and networks and to strengthen the logistics clusters, there have been few studies on what effects the spatial concentration of logistics businesses has on production activities of the logistics industry. Considering the current situation, the results of this study will serve as a theoretical basis for supporting the policies on logistics clusters. As a result of estimation from a panel data model as in the logistics industry growth model (Model 1), the location quotient (LQ) and the concentration type dummy variables were found to be statistically significant, and the classification and concentration of logistics businesses according to their spatial characteristics was found to contribute to the growth of the logistics industry.
\end{abstract}

Keywords : Logistics Industry, Growth of Logistics Industry, Gross Regional Domestic Product

\section{INTRODUCTION}

$S_{\text {outh Korea is one of the most heavily dependent }}$ countries on foreign economies. As a result, most of the corporate activities, ranging from procurement to sales, share logistics flows. Efficient support of international logistics is essential in the globalized business competition, and an efficient system is needed. Also, in recognition of the importance of the logistics industry in Korea, the Ministry of Land, Infrastructure and Transport and the Ministry of Maritime Affairs and Fisheries jointly develop and operate a network with major logistics hubs (logistics clusters) through the "National Logistics Framework Plan (2016-2025), and are putting a lot of effort into building additional clusters. However, the central and local governments have not been able to actually identify which areas are concentrated more in a certain city or province, and which areas are regional deviations in the logistics industry. In addition, it was found that the causes of the agglomeration of the logistics industry

Revised Manuscript Received on July 22, 2019.

Taek-Won Kim, Kyung-In Women's University, International Trade, 21041, Republic of Korea. E-mail: cauktw@gmail.com

Tae-Hwan Kim, Global Business Administration, An-Yang University, 14028, Republic of Korea. E-mail: kthwancau @ naver.com were different, with the natural occurrences and local government policies.

Therefore, the purpose of this study was to identify spatial agglomeration by region and to identify whether these spatial variables affect the growth of the logistics industries, by which to present policy implications for national and local governments' logistics industries.

\section{METHOD OF RESEARCH}

\section{A. Scope of Research}

The model of this research can be classified into the observed variables and latent variables.

The definition of logistics business was defined as logistics industry by classifying it as transport, logistics facilities operation and logistics service industries, and it was defined with the definitions that were given in the Framework Plan for National Logistics (2016-2025) issued by the Ministry of Land, Infrastructure and Transport and the Ministry of Maritime Affairs and Fisheries. On the other hand, the academic sector uses 'logistics companies' by defining some or all of them in the frameworks of the classification of transport businesses in the Korean Standard Industry Classification (10th) based on the purpose of research.

The data in this study used raw data from the transportation industry of the national survey provided by the National Statistical Office (MDIS). The raw data provide only until section, division and classifications of the industrial classification codes, and does not provide data up to the detail class due to privacy reasons. In addition, there were differences in data from year to year due to the integration and absorption of the city or promotion from county to city in the process of collecting data for many years.

\section{B. Analysis Procedure for Research}

The research procedures are as follows: In the first phase, LQ coefficients were derived to identify the degree of specialization of logistics businesses in each city and county, using the number of logistics companies in the cities and counties nationwide. The analysis period is five years from 2010-2014, and the statistical package for the analysis derived LQ coefficients for each city and county using STATA 14.2. This LQ factor was then used to derive the type of logistics industry during the analysis phase.

In the second phase, the Getis-Ord ( $\mathrm{G}$ statistics) index derived regional or integrated

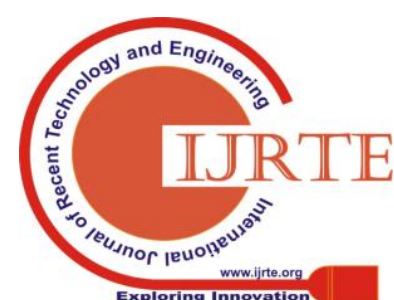


points of industrial activity,

trends and degree of agglomeration. The analysis period is five years from 2010-2014, and statistical packages for the analysis used the hotspot analysis package in Arc GIS 10.5. This G-statistics was then used to derive the classification of the logistics industry in the next phase.

In the third phase, LQ and G statistics by region which derived from phase 1 and 2 to were used to derive potential cluster areas, cluster areas, specialized areas, and unrelated areas. This allows understanding of the spatial patterns of logistics industries across the country and can be used as dummy variables during panel recovery analysis that was carried out later.

The fourth phase is the process of performing causal analysis of the study model using the variables derived in the phase 1 to 3 . Dependent variables are set as GRDP, which represents the regional gross domestic product of the logistics business, as a model.

\section{Selection of variables}

Factors were selected to extract the factors that influence the spatial agglomeration of logistics businesses' growth below the [Table- I].

Table- I: Summary of Research Hypothesis

\begin{tabular}{|c|c|c|c|c|}
\hline Classification & \multicolumn{2}{|l|}{ Variable } & Unit & Definition \\
\hline $\begin{array}{l}\text { Dependent } \\
\text { Variable }\end{array}$ & \multicolumn{2}{|c|}{ Logistics GRDP } & Billion & $\begin{array}{l}\text { Regional Gross } \\
\text { Domestic Product of } \\
\text { the Logistics } \\
\text { (GRDP) }\end{array}$ \\
\hline \multirow{9}{*}{$\begin{array}{l}\text { Explanatory } \\
\text { variable }\end{array}$} & \multirow[b]{2}{*}{$\begin{array}{l}\text { Spatial } \\
\text { Distribution } \\
\text { of Industry }\end{array}$} & LQ & Index & Location Index \\
\hline & & $\begin{array}{l}\text { Spatial } \\
\text { cluster type }\end{array}$ & Pile & $\begin{array}{l}\text { Potential cluster } \\
\text { area (reference } \\
\text { group), specialized } \\
\text { area, cluster area, } \\
\text { unrelated area }\end{array}$ \\
\hline & \multirow[b]{2}{*}{$\begin{array}{l}\text { Scale of } \\
\text { Industry }\end{array}$} & Trucks & Trucks & $\begin{array}{l}\text { Number of truck } \\
\text { registrations in city, } \\
\text { county and district }\end{array}$ \\
\hline & & $\begin{array}{l}\text { Regular } \\
\text { employee in } \\
\text { Logistics in } \\
\text { relation to } \\
\text { population }\end{array}$ & $\%$ & $\begin{array}{l}\text { The ratio of the } \\
\text { number of regular } \\
\text { employees in the } \\
\text { logistics industry to } \\
\text { the population in the } \\
\text { municipal and } \\
\text { provincial units }\end{array}$ \\
\hline & \multirow{3}{*}{$\begin{array}{l}\text { Regional } \\
\text { Factors }\end{array}$} & $\begin{array}{l}\text { Population } \\
\text { density }\end{array}$ & person / & Population density \\
\hline & & $\begin{array}{l}\text { Fluctuation } \\
\text { rate of land } \\
\text { price }\end{array}$ & $\%$ & $\begin{array}{l}\text { Land price } \\
\text { fluctuation rate of } \\
\text { city, county and } \\
\text { district units }\end{array}$ \\
\hline & & $\begin{array}{l}\text { Fiscal } \\
\text { self-reliance } \\
\text { ration }\end{array}$ & $\%$ & $\begin{array}{l}\text { (Local and non-tax } \\
\text { revenue/General } \\
\text { accounting } \\
\operatorname{tax}) \times 100\end{array}$ \\
\hline & \multicolumn{2}{|c|}{ GRDP in Manufacturing } & Billion & Billion \\
\hline & \multicolumn{2}{|c|}{ Cities and Provinces } & Pile & Pile \\
\hline
\end{tabular}

\section{FACTORS AFFECTING THE GROWTH OF LOGISTICS BY SPATIAL AGGLOMERATION}

\section{A. Overview of the model}

The LQ is an indicator of the degree of specialization of the industry and is recognized to be directly related to regional economic performance ([1-4]). This study expects LQ to be a positive factor for the GRDP in the logistics industry in this regard [Table-II].

Table-II: Growth Model of the Logistics Industry

\begin{tabular}{|l|l|}
\hline $\begin{array}{l}\text { Hypothesis 1-1 } \\
\text { (Model 1-1) }\end{array}$ & $\begin{array}{l}\text { The higher the spatial factors (LQ, spatial integration } \\
\text { type) in the logistics industry, the more likely it will } \\
\text { have a positive impact on the GRDP in the logistics } \\
\text { industry. }\end{array}$ \\
\hline $\begin{array}{l}\text { Hypothesis 1-2 } \\
\text { (Model 1-2 }\end{array}$ & $\begin{array}{l}\text { The spatial factors (LQ, spatial integration type) in the } \\
\text { logistics industry will have significant differences in the } \\
\text { GRDP in the logistics industry depending on the region. }\end{array}$ \\
\hline
\end{tabular}

Cluster-based economic development is not an 'answer' but can produce sustainable and meaningful results and is part of a policy agenda aimed at directly strengthening the capabilities of the urbanized economy[5]. In this light, the study divided the type of agglomeration according to spatial agglomeration into (potential) clusters, cluster areas, specialized areas, and unrelated areas[6]. In other words, depending on the type of spatial agglomeration in the logistics industry, it is expected to serve as a positive factor for the GRDP in the logistics industry. In addition, significant differences in the logistics industry GRDP for differences in regional areas were identified. Therefore, the size or size of the industry is a regionalized economic variable that affects revenue, increase in the number of workers, innovation, and location selection because economies of scale can occur by region([7-8]).

This study is intended to explore the question of whether the GRDP in the logistics industry grows with spatial factors in the logistics industry. For that reason, the hypothesis was tested by setting up a 'material industry growth model'. The hypothesis was set up with two hypotheses: First, hypothesis 1-1 analyzed whether the higher the spatial factors (LQ, spatial integration type) of logistics, the higher the effect of the positive (+) on the GRDP of logistics. Second, Hypothesis 1-2 examined whether spatial factors in logistics (LQ, spatial agglomeration type) exist in the GRDP of logistics industry depending on the region, and further analyzed through the modified model.

\section{B. Spatial Pattern Analysis of Logistics by Region}

The spatial analysis for 2014 for logistics was classified as a potential cluster area if the $Z_{-}\left(G_{-} i^{\wedge *}\right)$ (statistics of $G$ ) and LQ coefficients were $L Q \geq 1$ and $Z_{-}\left(G_{-} i^{\wedge *}\right) \geq 1.96$ [9-10].

First, a total of six (potential) clusters were analyzed for 2014. Seoul is Yangcheon-gu and Gangseo-gu, while Gyeonggi Province is analyzed as Ansan, Gangwon Province is Wonju, Chungcheongnam-do is Cheonan, Jeollanam-do is Gwangyang and Yeosu, and Gyeongsangnam-do Yangsan and Gimhae. Some of 
these areas were previously called integrated or cluster areas, and the methods and feasibility of the analysis were demonstrated to reflect the reality quantitatively and economically.

In 2013 (potential) cluster areas, there is no difference between cities and provinces, and only one within the city is different. Gangseo-gu is a cluster of Gimpo Airport, Incheon International Airport and logistics complexes in the Seoul metropolitan area. It can be seen that the statistical figures are increasing time by time. In the case of Asan, Chungcheongnam-do, in 2012, it was deemed reasonable when compared with 2011 and 2013 that the formation of a national industrial park and the logistics cluster were in line.

In case of 2011, potential clusters were derived from Seoul Metropolitan Government, Jeollabuk-do, Jeollanam-do, Gyeongsangnam-do and parts of Chungcheongbuk-do has been drawn as a potential cluster area, with Iksan City, Gimje City and Wanju County centered around Jeonju.

\section{Testing of the model}

To test the growth model of the logistics industry, hypothesis 1-1 conducted an analysis of the positive effects on the logistics industry's GRDP, with the higher spatial factors (LQ, spatial integration type) of the logistics industry. Further, the test was carried out on the assumption that spatial factors in logistics (LQ, spatial integration type) would have a significant difference in the GRDP of logistics service depending on the Area. The main factor that causes the growth of logistics industry is empirically demonstrated by the increasing spatial factors (LQ, spatial cluster type) of the logistics industry, as shown in the preceding study.

The main purpose of this study was to test the location patient (LQ) of logistics by city, county and district and whether the spatial integration type of logistics company affects the logistics industry GRDP. Here, the logistics location coefficient is an indicator of the relative importance of the logistics industry in the metropolitan area where the municipality is located, indicating the relative degree of specialization of the logistics industry.

In addition, the spatial integration type is a cross-referenced comparison of the location coefficient LQ and the spatial autocorrelation statistic $G$ statistics, dividing each city and county into cluster areas, cluster areas, specialized areas and non-related areas.

\section{A. Panel analysis results}

The main purpose of this study was to test the location patient (LQ) of logistics by city, county and district and whether the spatial integration type of logistics company affects the logistics industry GRDP. Here, the logistics location coefficient is an indicator of the relative importance of the logistics industry in the metropolitan area where the municipality is located, indicating the relative degree of specialization of the logistics industry.

In addition, the spatial integration type is a cross-referenced comparison of the location coefficient LQ and the spatial autocorrelation statistic $\mathrm{G}$ statistics, dividing each city and county into cluster areas, cluster areas, specialized areas and non-related areas.
For statistical models for testing, the panel model was applied as a methodology for capturing variability of logistics GRDP within and between city and county districts over two years in 2013 and 2014. Also, the panel model was applied for the period from 2010 to 2014 (five years) in accordance with the dependent variables (area GRDP). Panel models can expect more efficient estimates because they increase the number of observations for the same number of cities and counties compared to the cross-section regression model, and allow researchers to control unidentifiable city and district heterogeneity [Table-III].

In order to test the growth model of the logistics industry, the LQ and spatial integration type showing the distribution of space in the industry were presented, the number of freight car registrations showing the scale of the industry, and the ratio of the number of regular workers in the logistics business to the population was presented as shown in table-III. Also, the population density, fiscal self-reliance, and land price fluctuation rates were presented as factors to represent the region, and the variables were carried out as explanatory variables by including the manufacturing GRDP. The joint OLS model, the fixed effect panel model, and the probability effect panel model was estimated with the logistics industry GRDP as dependent variables.

In the case of a joint OLS model that ignores panel structure, the LQ was shown to have a negative (-) effect on logistics. This has been shown to be inconsistent with the theory of spatial agglomeration of the industry described in the preceding research and the design of research, which suggests that the panel model is more appropriate as an analytical methodology because simple linear regression models, such as the joint OLS, produce biased estimates.

Therefore, Model 1-1 should follow the fixed and probability effects analysis methods, and the choice of the two models will be followed by the later selection of the appropriate model through the Hausman test. The Hausman test determined that the p-value was less than 0.05 with 0.00 and therefore a fixed-effect model was chosen [Table-III].

First, the analysis of the fixed effect model for model 1-1 showed that the explanatory variables account for $14.7 \%$ of the variation in the logistics GRDP, which is the dependent variable as shown in table-III. It was also found that the changes in the logistics GRDP within the area were described by $38.88 \%$ and the changes in the logistics GRDP between the areas.

The LQ was deemed not statistically significant. Rather than the lack of a link between LQ and logistics GRDP, it is believed that the number of registered truckloads and the number of regular workers in the logistics industry relative to the population will generate multicollinearity and LQ.

The spatial agglomeration type (community area, cluster area, specialized area, non-related area) was set as a dummy variable, and the reference category of spatial agglomeration type was set as a cluster area. Because the cluster area was developed as a reference category in the analysis, the sign of another type of agglomeration type dummy should have a negative (-) orientation to indicate

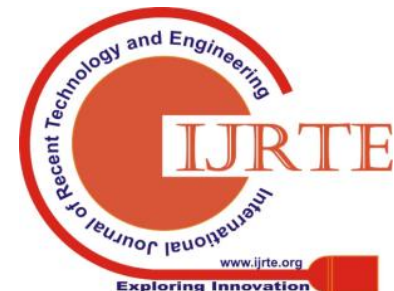


that the cluster area has a positive effect on logistics GRDP compared to other areas. The analysis results show that cluster areas have a significant impact on logistics GRDP at $90 \%$ confidence level, with a coefficient of -102.16 per unit increase compared to the cluster areas. Specialized areas were analyzed to have a significant impact on logistics GRDP at $99 \%$ confidence level,

with a coefficient of -103.36 per unit increase compared to cluster areas [Table-III].

In addition, the non-related area was analyzed to have a significant effect on logistics GRDP at a confidence level of $99 \%$, with a coefficient of -106.61 compared to the cluster area. This can be statistically confirmed by the cluster area to increase logistics GRDP. Land price fluctuation rate was analyzed to have a significant effect on the $90 \%$ confidence level with the coefficient being 7.54. The number of truck registrations was analyzed to have a significant effect on the coefficient of 0.09 , with a $95 \%$ confidence level. The number of workers in the logistics industry compared to the population was analyzed to have a significant impact at the $95 \%$ confidence level with the coefficient being 11345.81 [Table-III].

The model 1-1 showed that the number of truck registrations and logistics workers who represent the spatial distribution of the industry and the size of the industry have a significant impact on the logistics industry GRDP. Also, the larger the spatial distribution of logistics industry and the larger the size of logistics industry, the higher the logistics industry GRDP, and the growth of the logistics industry in the region was identified as both a factor and an appropriate model [Table-III].

Table- III: Analysis of the Logistics Industry Growth Model (model 1-1)

\begin{tabular}{|c|c|c|c|}
\hline Variable & Joint OLS Model & $\begin{array}{l}\text { Fixed Effect } \\
\text { Model }\end{array}$ & $\begin{array}{l}\text { Probability } \\
\text { Effect Model }\end{array}$ \\
\hline \multirow{2}{*}{ LQ } & $-1085.12 * * *$ & 13.08 & 1.11 \\
\hline & $(392.46)$ & $(28.67)$ & $(30.25)$ \\
\hline \multirow{2}{*}{$\begin{array}{l}\text { Agglomeration Type } \\
\text { Dummy: Cluster } \\
\text { Area }\end{array}$} & $-1598.54 * *$ & $-102.16^{*}$ & $-128.90 * *$ \\
\hline & $(669.79)$ & $(58.29)$ & $(61.45)$ \\
\hline \multirow{2}{*}{$\begin{array}{l}\text { Agglomeration Type } \\
\text { Dummy: } \\
\text { Specialized Area }\end{array}$} & $-1179.62 * * *$ & $-103.36 * * *$ & $-114.39 * * *$ \\
\hline & $(397.07)$ & $(38.70)$ & $(40.82)$ \\
\hline \multirow{2}{*}{$\begin{array}{l}\text { Agglomeration Type } \\
\text { Dummy: non-related } \\
\text { Area }\end{array}$} & $-1552.70 * * *$ & $-106.61 * * *$ & $-120.07 * * *$ \\
\hline & $(443.33)$ & $(40.53)$ & $(42.72)$ \\
\hline \multirow{2}{*}{$\begin{array}{l}\text { Manufacturing } \\
\text { GRDP } \\
\text { (billion won) }\end{array}$} & -0.02 & 0.01 & 0.01 \\
\hline & $(0.01)$ & $(0.01)$ & $(0.01)$ \\
\hline \multirow{2}{*}{ Population Density } & 0.02 & 0.04 & $0.06^{* * * *}$ \\
\hline & $(0.01)$ & $(0.04)$ & $(0.02)$ \\
\hline \multirow{2}{*}{$\begin{array}{l}\text { Fiscal Self-reliance } \\
\text { Ratio }\end{array}$} & $44.30 * * *$ & -0.20 & 1.19 \\
\hline & $(7.57)$ & $(1.56)$ & $(1.62)$ \\
\hline \multirow{2}{*}{$\begin{array}{l}\text { Fluctuation Rate of } \\
\text { Land Price }\end{array}$} & 123.72 & $7.54 *$ & $7.43 *$ \\
\hline & $(92.05)$ & $(3.82)$ & $(3.99)$ \\
\hline
\end{tabular}

\begin{tabular}{|l|l|l|l|}
\hline \multirow{2}{*}{$\begin{array}{l}\text { Number of truck } \\
\text { registrations }\end{array}$} & -0.05 & $0.09^{* *}$ & $0.09^{* * *}$ \\
\cline { 2 - 4 } & $(0.07)$ & $(0.04)$ & $(0.04)$ \\
\hline $\begin{array}{l}\text { Number of regular } \\
\text { workers in the } \\
\text { logistics industry } \\
\text { compared to } \\
\text { population }\end{array}$ & $17133.31^{* * *}$ & $11345.81^{* * *}$ & $12372.49^{* * * *}$ \\
\cline { 3 - 4 } & $(3211.41)$ & $(1603.52)$ & $(1599.66)$ \\
\hline \multirow{2}{*}{ Constant Term } & $1431.41^{* *}$ & 50.51 & 78.45 \\
\cline { 2 - 4 } & $(651.44)$ & $(173.27)$ & $(158.50)$ \\
\hline $\mathrm{N}$ & 365 & 365 & 365 \\
\hline $\mathrm{R}^{2}$ within & \multirow{2}{*}{$\mathrm{R}^{2}=0.2782$} & 0.3888 & 0.3843 \\
\cline { 3 - 4 } $\mathrm{R}^{2}$ between & 0.1522 & 0.1595 \\
\cline { 3 - 4 } $\mathrm{R}^{2}$ overall & & 0.1470 & 0.1516 \\
\hline Hausman Test & & Chi-Sq. $=26.98, \mathrm{p}=0.0003$ \\
\hline
\end{tabular}

Dependent variable: Logistics industry GRDP (billion won)

( ) is standard error; *p<0.10,**p $<0.05, * * * p<0.01$

In addition, the non-related area was analyzed to have a significant effect on logistics GRDP at a confidence level of $99 \%$, with a coefficient of -106.61 compared to the cluster area. This can be statistically confirmed by the cluster area to increase logistics GRDP. Land price fluctuation rate was analyzed to have a significant effect on the $90 \%$ confidence level with the coefficient being 7.54. The number of truck registrations was analyzed to have a significant effect on the coefficient of 0.09 , with a $95 \%$ confidence level. The number of workers in the logistics industry compared to the population was analyzed to have a significant impact at the 95\% confidence level with the coefficient being 11345.81 [Table-III].

The model 1-1 showed that the number of truck registrations and logistics workers who represent the spatial distribution of the industry and the size of the industry have a significant impact on the logistics industry GRDP. Also, the larger the spatial distribution of logistics industry and the larger the size of logistics industry, the higher the logistics industry GRDP, and the growth of the logistics industry in the region was identified as both a factor and an appropriate model [Table-III].

Table- IV: Analysis of the Logistics Industry Growth Model (model 1-2)

\begin{tabular}{|l|l|l|l|}
\hline Variable & Joint OLS Model & $\begin{array}{l}\text { Fixed Effect } \\
\text { Model }\end{array}$ & $\begin{array}{l}\text { Probability Effect } \\
\text { Model }\end{array}$ \\
\hline \multirow{2}{*}{ LQ } & 85.87 & $62.59 *$ & $57.98^{*}$ \\
\cline { 2 - 4 } & $(318.45)$ & $(32.70)$ & $(34.27)$ \\
\hline $\begin{array}{l}\text { Agglomeration } \\
\text { Type Dummy: } \\
\text { Cluster Area }\end{array}$ & $-1271.55^{*}$ & -82.43 & -114.50 \\
\cline { 2 - 4 } & $(687.67)$ & $(67.68)$ & $(70.98)$ \\
\hline $\begin{array}{l}\text { Agglomeration } \\
\text { Type Dummy: } \\
\text { Specialized Area }\end{array}$ & $-1072.35 * * *$ & $-87.89 *$ & $-99.86^{* *}$ \\
\cline { 2 - 4 } & $(409.99)$ & $(44.81)$ & $(47.04)$ \\
\hline Agglomeration & $-939.17 * *$ & $-87.51 *$ & $-101.71 * *$ \\
\hline
\end{tabular}




\begin{tabular}{|c|c|c|c|}
\hline Variable & Joint OLS Model & $\begin{array}{l}\text { Fixed Effect } \\
\text { Model }\end{array}$ & $\begin{array}{l}\text { Probability Effect } \\
\text { Model }\end{array}$ \\
\hline $\begin{array}{l}\text { Type Dummy: } \\
\text { non-related Area }\end{array}$ & $(443.38)$ & $(46.98)$ & $(49.26)$ \\
\hline \multirow{2}{*}{$\begin{array}{l}\text { Manufacturing } \\
\text { GRDP } \\
\text { (billion won) }\end{array}$} & $-0.03 * *$ & 0.01 & 0.01 \\
\hline & $(0.01)$ & $(0.02)$ & $(0.01)$ \\
\hline \multirow{2}{*}{ Population Density } & 0.02 & 0.05 & $0.07 * * *$ \\
\hline & $(0.01)$ & $(0.05)$ & $(0.02)$ \\
\hline \multirow{2}{*}{$\begin{array}{l}\text { Fiscal Self-reliance } \\
\text { Ratio }\end{array}$} & $49.70 * * *$ & -0.87 & 0.97 \\
\hline & $(6.89)$ & $(1.82)$ & $(1.87)$ \\
\hline \multirow{2}{*}{$\begin{array}{l}\text { Fluctuation Rate of } \\
\text { Land Price }\end{array}$} & 100.28 & $15.80 * * *$ & $16.52 * * *$ \\
\hline & $(95.26)$ & $(4.22)$ & $(4.43)$ \\
\hline \multirow{2}{*}{ Constant Term } & -48.93 & 233.35 & 234.24 \\
\hline & $(605.82)$ & $(195.65)$ & $(164.47)$ \\
\hline $\mathrm{N}$ & 365 & 365 & 365 \\
\hline $\mathrm{R}^{2}$ within & \multirow{3}{*}{$\mathrm{R}^{2}=0.2201$} & 0.1455 & 0.1379 \\
\hline $\mathrm{R}^{2}$ between & & 0.0717 & 0.0812 \\
\hline $\mathrm{R}^{2}$ overall & & 0.0681 & 0.0769 \\
\hline \multicolumn{2}{|l|}{ Hausman Test } & \multicolumn{2}{|c|}{ Chi-Sq. $=42.61, p=0.0000$} \\
\hline
\end{tabular}

Dependent variable: Logistics industry GRDP (billion won)

( )is standard error; *p $<0.10, * * \mathrm{p}<0.05, * * * \mathrm{p}<0.01$

This is a model that excludes the number of registered freight cars and the number of commercial workers in the logistics industry, which is a factor that indicates the size of the logistics industry. As in other correlation analyses, this increases the number of multiple co-linearity with logistics-related explanatory variables, and the standard error as seen in Table-IV. Therefore, the panel model was estimated by eliminating these two variables (number of truck registrations and Number of regular workers in the logistics industry compared to population) by understanding that the LQ was not significant. By analyzing the pure logistics space factor of the logistics industry, the model can suggest that regional characterization and spatial agglomeration in the logistics industry are statistically affecting the logistics industry GRDP. Similar to the previous model 1-1, a joint OLS, a fixed-effect model, and a probability-effect model were conducted, and a Hausman test was performed to select a suitable panel model. Statistical basis for selecting a fixed-effect model with a significant probability of less than 0.05 has been prepared and adopted [Table-IV].

Looking at the analysis results of model 1-2 the variables in the model were analyzed to account for $6.81 \%$ of the logistics industry GRDP overall, $14.55 \%$ in within area and $7.17 \%$ in between area. The LQ was statistically significant at a confidence level of 62.59 , with a positive sign indicating that the spatial characteristics of the logistics industry resulted in the logistics industry GRDP [Table-IV].

In addition, the differences between spatial agglomeration types were found to have significant impacts on the cluster area compared to the specialized areas in the fixed effect model, the cluster area has a higher logistics GRDP than the

non-relationship areas, the cluster area has a higher coefficient of cluster area (-82.43), the cluster area (-87.89), and the independent area (-87.51) and the confidence level of $90 \%$. Among the regional variables, the land price fluctuation rate was shown to have a significant effect on the $99 \%$ confidence level. These $\mathrm{R}^{2}$ values are lower than other linear regression analyses. This is because the number of truck registrations and the number of logistics-related commercial workers affecting the logistics industry's GRDP were excluded from the model. The main purpose of this study was not to focus research on $\mathrm{R}^{2}$ because it was focused on establishing hypotheses and statistically testing the theories of the study, not on discovering models that would explain variability highly [Table-IV].

Model 1-3 was statistically identified only by a pooled OLS model and a probability-effect model. This is because it is not possible to make statistical estimates when adding a pile of regions in a fixed-effect model. After the two models were analyzed separately, the Breusch-Pagan Lagrange multiplier (LM) test was performed on whether the model of the joint OLS model and the probability-effect model were more appropriate. The analysis showed that the size of the Significance Probability (p-value) was 0.0523 and that the probability effect model was more suitable than the OLS model at the $90 \%$ confidence level [Table-V].

Table-V: Breusch-Pagan Lagrange Multiplier Test

\begin{tabular}{|l|l|}
\hline Test Statistics & Significance Probability (p-value) \\
\hline Chi-Sq.= 2.63 & 0.0523 \\
\hline
\end{tabular}

Table-VI: An Analysis of Regional Differences in the Logistics Industry Growth Model (model 1-3)

\begin{tabular}{|l|l|l|}
\hline Variable & Joint OLS Model & Fixed Effect Model \\
\hline LQ & 118.22 & $56.71^{*}$ \\
\hline LQ & $(323.09)$ & $(33.95)$ \\
\hline $\begin{array}{l}\text { Agglomeration Type } \\
\text { Dummy: Cluster Area }\end{array}$ & -985.83 & -108.82 \\
\hline 집적유형더미: 군집지역 & $(703.78)$ & $(70.31)$ \\
\hline $\begin{array}{l}\text { Agglomeration Type } \\
\text { Dummy: Specialized Area }\end{array}$ & $-1051.74^{* *}$ & $-101.66^{* *}$ \\
\hline 집적유형더미: 특화지역 & $(426.70)$ & $(46.60)$ \\
\hline $\begin{array}{l}\text { Agglomeration Type } \\
\text { Dummy: non-related Area }\end{array}$ & $-894.58^{* *}$ & $-103.69^{* *}$ \\
\hline 집적유형더미: 무관지역 & $(454.64)$ & $(48.80)$ \\
\hline $\begin{array}{l}\text { Manufacturing GRDP } \\
\text { (billion won) }\end{array}$ & $-0.03 * * *$ & 0.00 \\
\hline $\begin{array}{l}\text { 제조업 GRDP } \\
\text { (십 억원) }\end{array}$ & $(0.01)$ & $(0.01)$ \\
\hline Population Density & 0.01 & $(0.02)$ \\
\hline 인구밀도 & $(0.02)$ & 0.64 \\
\hline \begin{tabular}{l} 
Fiscal Self-reliance Ratio \\
\hline
\end{tabular} & $41.87^{* * * *}$ & 0.03 \\
\hline
\end{tabular}




\begin{tabular}{|c|c|c|}
\hline Variable & Joint OLS Model & Fixed Effect Model \\
\hline 재정자립도 & $(8.53)$ & $(1.86)$ \\
\hline $\begin{array}{l}\text { Fluctuation Rate of Land } \\
\text { Price }\end{array}$ & $236.30 * *$ & $16.43 * * *$ \\
\hline 지가변동률 & $(110.26)$ & $(4.39)$ \\
\hline Gyeongsangnam-do & -195.36 & 50.57 \\
\hline 경남 & (321.94) & (595.63) \\
\hline Gyeongsangbuk-do & -41.05 & 9.33 \\
\hline 경북 & $(316.95)$ & $(562.19)$ \\
\hline Gwangju & 137.03 & -19.43 \\
\hline 광주 & $(484.23)$ & (906.41) \\
\hline Daegu & -421.94 & -137.73 \\
\hline 대구 & $(438.54)$ & (776.16) \\
\hline Daejeon & -6.46 & 15.96 \\
\hline 대전 & $(485.13)$ & $(905.58)$ \\
\hline Busan & -336.01 & -126.95 \\
\hline 부산 & (378.74) & $(653.32)$ \\
\hline Seoul Metropolitan Area & 584.87 & $1163.19^{* *}$ \\
\hline 수도권 & $(370.88)$ & $(534.16)$ \\
\hline Ulsan & -447.11 & 33.98 \\
\hline 울산 & $(508.06)$ & (910.37) \\
\hline Jeollanam-do & 93.37 & 1.50 \\
\hline 전남 & $(305.12)$ & $(567.57)$ \\
\hline Jeollabuk-do & 108.38 & 4.88 \\
\hline 전북 & (341.98) & $(636.32)$ \\
\hline Chungcheongbuk-do & 6.62 & 39.69 \\
\hline 충북 & $(366.11)$ & $(665.87)$ \\
\hline Constant Term & -140.18 & 86.80 \\
\hline 상수항 & $(634.28)$ & $(425.59)$ \\
\hline $\mathrm{N}$ & 365 & 365 \\
\hline $\mathrm{R}^{2}$ within & $\mathrm{R}^{2}=0.2515$ & 0.1401 \\
\hline $\mathrm{R}^{2}$ between & $\mathrm{R} 2=0.2515$ & 0.1363 \\
\hline $\mathrm{R}^{2}$ overall & $\mathrm{R} 2=0.2515$ & 0.1423 \\
\hline
\end{tabular}

Dependent variable: Logistics industry GRDP (billion won)

( )is standard error; * $\mathrm{p}<0.10,{ }^{*} \mathrm{p}<0.05, * * * \mathrm{p}<0.01$

Model 1-3 explains $14.23 \%$ of the logistics industry GRDP overall, $14.01 \%$ in the region and $13.63 \%$ in the region. The analysis results for model 1-3 showed that the probability effect model of adding local dummy variables while considering the probability effect of city and county units, the spatial factor of the industry, LQ, has a significant effect at

the coefficient of 56.71 and the confidence level of $90 \%$, and the specialized area of spatial agglomeration type is analyzed to have a significant effect at the $95 \%$ confidence level [Table-VI].

Also, the non-related area was analyzed to have a significant effect on the coefficient at -103.69 , with a $95 \%$ confidence level. This is statistically significant and has been analyzed in accordance with the code theory. In the probability effect model, other regional dummies were not statistically significant, but the dummy variables in the Seoul metropolitan area were significantly shown at a coefficient of 1163.19 with a 95\% confidence level, indicating that logistics GRDPs in the metropolitan area were higher than in other areas [Table-VI].

3.4.2. Summary of analysis results

The hypothesis of the study was established earlier and the hypothesis was tested through empirical analysis. The logistics industry growth model looked into whether spatial factors in the logistics industry affected the GRDP growth in the logistics industry. Model 1-1 of hypothesis 1-1 showed that among the spatial factors, LQ was not statistically significant, and spatial integration was statistically significant. This was seen as a matter of statistical redundancy rather than an interpretation that the specialization of logistics industry does not affect the growth of the GRDP in the logistics industry, and the spatial agglomeration type of logistics industry was analyzed to have a significant impact on the growth of the GRDP in the logistics industry. In other words, it is thought that since spatial agglomeration in logistics has a positive effect on the growth of logistics, it should be possible to create a positive (+) external effect through policy support and inducement to concentrate LQ in a single space. Additionally, as a factor indicating the size of the logistics industry, it was able to identify the larger the number of trucking registered and regular logistics workers compared to the population, the higher the GRDP of the logistics industry. As a result, it is believed that the government will need to provide policy infrastructure support in an integrated manner so that the logistics industry can grow in size and be affected by spatial aggregation.

Model 1-2 of hypothesis 1-2 was found to have a significant effect on the GRDP of logistics by LQ and cluster area. This analysis was conducted with control variables such as manufacturing GRDP, population density, fiscal self-reliance, and land price fluctuation. This was major in analyzing the spatial factors of pure logistics business, and regional specialization and spatial integration of logistics business were analyzed to influence the logistics industry GRDP. The logistics industry should be spatially agglomerated, and industrial specialization can be seen as a factor that raises the GRDP in the logistics industry.

Model 1-3 of Hypothesis 1-2 is a model that adds dummy of areas to Model 1-2, which statistically looked at whether LQ and spatial agglomeration differed depending on the region. As a result, we confirmed that the logistics 
industry GRDP in the Seoul metropolitan area is higher than other regions. This shows that the number of regional internal divisions in the logistics industry in Seoul, Gyeonggi Province and Incheon Metropolitan City is relatively higher than in other regions.

\section{CONCLUSION}

This study sought to explore the growth engines of the logistics industry in the future by identifying the factors that spatial factors of the logistics industry affect the spatial factors of the logistics industry.

Logistics infrastructure should cover physical infrastructure in addition to efficient delivery system construction. Accordingly, existing and old infrastructure facilities such as shipping facilities, roads, bridges and ports should be improved and expanded.

The problem of the spatial agglomeration of logistics businesses is not only specific location, but also needs to draw a big outline for the establishment of hierarchical structure and linkage systems among logistics clusters by size and type of logistics industry in Korea. In other words, future management and operation of logistics facilities should focus on the efficient linkage between various logistics complexes and the establishment of organic networks beyond the single level of logistics facilities.

Each individual logistics complexes will compete with each other while securing their back space market, as presented through the exclusive competition model of Hoteling; one of the various theories studied in previous studies. The central government should support this inter-district competition system without violating market efficiency and in addition, it will be necessary to systematize the supply of logistics complexes throughout the country and implement a post-evaluation plan elaborately so that the functions of logistics complexes do not overlap spatially or invest under or over.

The implications of this study are as follows. Despite the fact that the National Logistics Master Plan (2016-2025) was established at a national level to build and operate the logistics bases and networks and to strengthen the logistics clusters, there have been few studies on what effects the spatial concentration of logistics businesses has on production activities of the logistics industry. Considering the current situation, the results of this study will serve as a theoretical basis for supporting the policies on logistics clusters. As a result of estimation from a panel data model as in the logistics industry growth model, the location quotient (LQ) and the concentration type dummy variables were found to be statistically significant, and the classification and concentration of logistics businesses according to their spatial characteristics was found to contribute to the growth of the logistics industry.

\section{REFERENCES}

1. M. Porter, "The Economic Performance of Regions" Regional Studies 37(6-7), 549-578, 2010

2. A. J. Scott, Regions and the World Economy: The Coming Shape of Global Production, Competition, and Political Order. Oxford: Oxford University Press, 1-159, 1998.

3. P. Krugman, "Increasing Returns and Economic Geography" Journal of Political Economy. 99(3), 483-499, 1991.

4. C. Baer, T. Brow, "Location Quotients: a Tool for Comparing Regional Industry Compositions" Indian's Workforce and Economy. 7(3), 1-3, 2006.

5. JPMorgan Chase \& Co. (2017) (https://www.jpmorganchase.com/corporate/Corporate-Responsibility/hel ping-metro-areas.htm)

6. Y. S. Roh, "Regional Economic Effect of Food Manufacturers: Spatial Concentration, Employment Growth, value-added," Ph.D. Thesis, Seoul National University, 2015.

7. J. V. Henderson, A. Kuncoro, M. Turner, "Industrial development in cities" Journal of Political Economy. 103(5), 1067-1090, 1995.

8. U. Kambhampati, P. McCann, "Regional Performance and Characteristics of Indian Manufacturing Industry" Regional Studies. 41(3), 281-294, 2007.

9. H. Y. Lee, Economic Geography. Bobmunsa, 2011.

10. P. Miller, R. Botham, H. Gibson, R. Martin, B. Moore, Business Clusters in the UK-A First Assessment. Report for the Department of Trade and Industry by a Consortium Led by Trends Business Research, Great Britain, 2001.

\section{AUTHORS PROFILE}

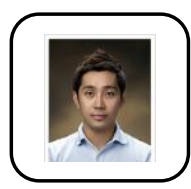

Taek-Won Kim Kyung-In Women's University, International Trade, 21041, Republic of Korea

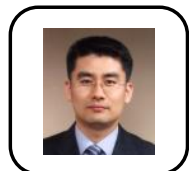

Tae-Hwan Kim Global Business Administration, An-Yang University, 14028, Republic of Korea 